\title{
A Three-Dimensional Model of Innovation within Flemish Non-Profit Sports Organisations
}

\author{
Joris Corthouts $^{\mathrm{a}}$, Mathieu Winand ${ }^{\mathrm{b}}$ and Jeroen Scheerder ${ }^{\mathrm{a}}$ \\ ${ }^{a}$ Department of Movement Sciences, University of Leuven, Belgium, Tervuursevest 101, \\ 3000 Leuven \\ ${ }^{b}$ Lunex University, L, 50 Avenue du Parc des Sports, 4671 Differdange
}

Joris Corthouts graduated in 2017 as a master in Physical Education and Movement Sciences (major in Sports Policy and Management). Since graduating, he worked as a scientific researcher within the Policy in Sports \& Physical Activity Research Group. He is currently preparing a thesis as a $\mathrm{PhD}$ candidate, with a focus on innovation within the non-profit sports sector as part of the Interuniversity Policy Research Centre on Sports 2017-2022.

Mathieu Winand, $\mathrm{PhD}$ is Professor of Sport Management at LUNEX International University of Health, Exercise and Sports in Luxembourg and Head of Department of International Sport Management. His research interests are in the area of sport governance, performance management and innovation in sport. Mathieu is Deputy Editor of Sport, Business and Management: An International Journal and Past Chair of the Strategic Interest Group on 'Managing Sport' at European Academy of Management (EURAM).

Jeroen Scheerder $(\mathrm{PhD}, \mathrm{MA}, \mathrm{MSc}, \mathrm{MScEd})$ has an educational background in Sport Sociology, Social and Cultural Anthropology, Movement and Sport Sciences, and Marketing. $\mathrm{He}$ is professor of sport policy and sport sociology in the Department of Movement Sciences, Faculty of Movement \& Rehabilitation Sciences (KU Leuven) where he heads the Policy in Sports \& Physical Activity Research Group. He is promotor-coordinator of the Interuniversity Policy Research Centre on Sports on behalf of the Flemish Government, and the academic coordinator of the KU Leuven Sport Policy \& Sport Management Program. He served as president of the European Association for Sociology of Sport (2014-2016), was visiting professor in sport sociology at the Faculty of Political \& Social Sciences, Ghent University (Belgium), was guest professor at the universities of Brussels, Cassino, Cologne, Jyväskylä, Kaunas, Nijmegen and Porto, and (co-)founded both the European MEASURE and POLIS Research Networks that focus on sport participation and sport policies/sport politics respectively. His research focuses on political and sociological aspects of sport and physical activity. He (co-)authored >85 international articles and >25 international book chapters, and (co-)supervised 16 doctoral theses. He is editor of The Rise and Size of the Fitness Industry in Europe: Fit for the Future? (2020), Running across Europe: The rise and size of one of the 
largest sport markets (2017), and Sport policy systems and sport federations: A cross-national perspective (2015), and co-editor of Functions of Sports Clubs in European Societies: A CrossNational Comparative Study (2020) (all by Palgrave Macmillan/Springer). 


\section{A Three-Dimensional Model of Innovation within Flemish Non-Profit Sports Organisations}

Research question: This study aims to address the limitations of current typologies and determinants of innovation by proposing a three-dimensional (3D) conceptual innovation model, in which three dimensions (i.e. 'form', 'nature' and 'goal') are related to each other, resulting in eight innovation types. Based on this model, this study first examines the extent to which voluntary sports clubs (VSCs), sports federations (SFs) and local sports authorities (LSAs) implement the innovation types differently. Second, the effects of managerial, organisational and environmental determinants on the eight innovation types are investigated.

Research methods: Online questionnaires were distributed to VSCs, SFs and LSAs. Key representatives were asked to describe and categorise each innovation that their organisation had implemented in the previous four years. In addition, they were asked for their opinion on management, structural organisational characteristics and environmental influences.

Results and Findings: Findings show that there are significant differences in the extent to which the eight innovation types are implemented by SFs, LSAs and VSCs. Also, the assumption that different innovation types relate to one or more managerial, organisational and environmental determinants is confirmed by logistic regression analyses.

Implications: As such, this study's model can serve as an extensive framework to identify innovation types in and outside a sporting context. Furthermore, the findings provide (sports) policymakers with insights into the innovativeness of (sports) organisations and how they can support it.

Keywords: innovation determinants; innovation types; local sports authorities; voluntary sports clubs; sports federations

WORD COUNT: 8,072 


\section{Introduction}

Innovation is broadly defined as "an idea, practice, or object that is perceived to be new by an individual or other unit of adoption" (Rogers, 2003, p. 11). There is an abundance of literature on the plural dimensions and determinants of innovation (Damanpour \& Schneider, 2006; Jaskyte, 2011). Although results from different research areas are mutually reinforcing, Rogers (2003) warns of the pitfalls of a diversified innovation research approach, which would either be inclined to standardise context-specific concepts such as innovation, or prevent comparisons by applying a set of too contextspecific research directions. Hence, studies present conflicting results regarding the determinants of organisations' innovativeness due to a too narrow or broad innovation definition (Subramanian \& Nilakanta, 1996). Because of the discrepancy between studies' findings on the degree and direction of determinants (Cooper, 1998; Corthouts et al., 2019; Damanpour, 1988), researchers argue for differentiation between types of innovation as a way to clarify conflicting results (Rowley et al., 2011). Within the resulting innovation typology studies, innovation types are distinguished by scholars in terms of one or more of their attributes. Innovation attributes are the perceived characteristics of an innovation type (such as the cost) (Baregheh et al., 2009; Rogers, 2003). When innovation types are studied in terms of possible opposite attribute combinations (e.g. high-low cost), this is referred to as a dichotomous dimension (Hoeber et al., 2015). The current innovation typology research is characterised by single attribute and unidimensional measurements (e.g. Damanpour, 1988; Hoeber et al., 2015; Morris, 2013). As each innovation possesses multiple dimensions simultaneously, it is argued that "under-specification of the innovation(s) being studied becomes problematic in that there can be little or no comparison of findings across studies" (Cooper, 1998, p. 493). After all, the determinants can vary between two 
innovation types of one dimension (such as product vs. process innovations) (Jaskyte, 2011), however, other/more differences may emerge when comparing two product innovations based on two opposing attributes (technical vs. administrative) of an extra dimension (such as 'form') (Corthouts et al., 2019). The three core dichotomous dimensions (with corresponding attributes) under investigation in this study are 'form' (product-process), 'nature' (technical-administrative) and 'goal' (social-commercial) (see Figure 1). 
Figure 1. Labelled Hierarchy of Concepts from Innovation Typology Research with Article Examples

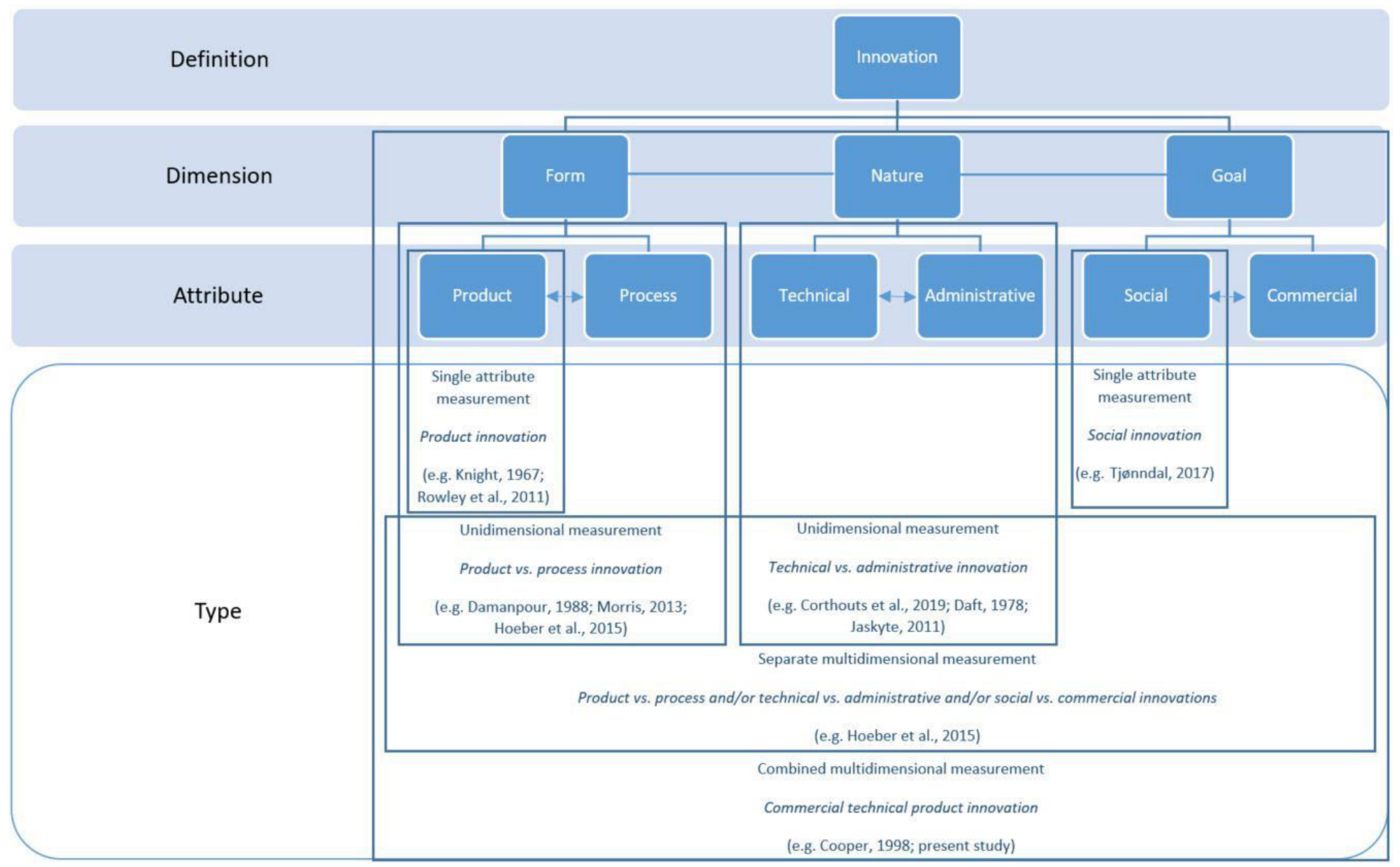


Current sports innovation research can be divided into six main themes (Tjønndal, 2016), namely innovation outputs (Balmer et al., 2012), processes (Hoeber \& Hoeber, 2012), entrepreneurs (Ratten, 2016), typologies (Winand et al., 2016), strategy in sports organisations (Hoeber et al., 2015; Wemmer et al., 2016) and determinants and strategic management (Winand et al., 2013). At the crossroads of multiple themes, the current study develops a conceptual (3D-)model that divides innovations into eight different types. Firstly, this research aims to contribute to the absent literature about innovation in different types of NPSOs by investigating the extent to which different innovation types are implemented by sports federations (SFs), local sports authorities (LSAs) and voluntary sports clubs (VSCs) in Flanders, Belgium. Secondly, elaborating on previous research (Hoeber \& Hoeber, 2012; Winand et al., 2016), the current study intends to investigate whether managerial, organisational and environmental determinants affect the implementation of the different innovation types. As such, this study aims to present an ameliorated model that can serve both as a theoretical basis for generating more comparable research across different domains (Cooper, 1998; Damanpour, 1988) and a practical tool for NPSOs and policymakers to consider various innovation types, taking into account the organisational characteristics. In summary, the following research questions (RQs) are addressed:

RQ1: To what extent do SFs, VSCs and LSAs implement innovations (differently)?

RQ2: Which determinants predict the implementation of the eight different types of innovation?

\section{Context}


The context of this research pertains to Flanders, which is one of the three community governments (besides the French- and German-speaking Communities) of the federal state of Belgium with a separate responsibility for sport (van Poppel et al., 2018). This study uses Scheerder's (2007) model, which builds on Ibsen and Jørgensen’s research (2002) in identifying types of sports organisations based on their distinct legitimacies ${ }^{1}$ (van Poppel et al., 2018), to investigate three major players on the non-profit side, namely VSCs, LSAs and SFs.

Concerning VSCs, Flanders counts around 28,000 VSCs (Sport Flanders, 2020). In comparison with most Western-European countries, there are many VSCs in Flanders, but with a small number of members (averaging 145) (Breuer et al., 2017; Claes et al., 2017). Regarding LSAs, Flanders is divided into 308 municipalities. In each of these municipalities there is a LSA, either as an independent body or as part of an organisation that is responsible for multiple policy areas. Finally, this study focuses on SFs that are recognised by the Flemish government. This involved a total of 70 SFs, of which 63 uni-SFs that offer competition in one sports branch, and seven multi-SFs that offer recreational services in several sports branches.

VSCs, LSAs and SFs were chosen because the non-profit sports policy in Flanders is the result of an interaction between these prototype sports providers, all three of which are largely dependent on volunteers (Scheerder et al., 2021) and do not strive for financial profit maximisation (Weisbrod, 2009), even though their policy level and degree of government control are different. In terms of their role, place and mutual interactions in the Flemish sports structure, VSCs at (sub)local level form the basic

\footnotetext{
${ }^{1}$ Even though all three NPSO types pertain to the non-profit side of the model, according to Scheerder (2007), VSCs are more likely to create an offer focused at social goals (e.g. social integration), LSAs at public goals (e.g. public prosperity) and SFs at common goals (combining aforementioned goals).
} 
providers for approximately one and a half million Flemish people to practice sport. VSCs receive support both from the SF(s), which represent(s) them at the Flemish level, and from the LSA of the municipality where they are active. As a result of the increasing competition from for-profit organisations (Vos \& Scheerder, 2014; Winand et al., 2013) and the decentralisation of the Flemish sports policy (van Poppel et al., 2018) in recent years, the boundaries between these different types of sports providers have become blurred (Gratton \& Taylor, 2000). Consequently, more emphasis has been placed on the role of LSAs and SFs no longer to act exclusively as regulators, but also as providers. Besides financially supporting VSCs, LSAs for instance ensure the exploitation of municipal sports infrastructure or the organisation of sports camps, mainly targeting disadvantaged groups (such as people living in poverty) for whom VSCs' membership is too expensive (van Poppel et al., 2018). Complementary to the VSCs' offer, SFs focus among other things on organising sports events. In this way, they aim to reach the individual sports participant (Scheerder et al., 2021). It can be expected that the organisation type is related to the type of innovation being implemented (Damanpour, 1991). In particular, SFs have implemented on average more general (administrative) innovations than sports-technical innovations (Winand et al., 2013). In turn, VSCs have implemented more administrative and process innovations (Hoeber et al., 2015). Since the focus from previous studies is on innovation within one type of organisation, this study aims to compare innovation types between organisation types (RQ1). Subsequently, when investigating determinants of each innovation type (RQ2), the organisation type is included as a control variable.

\section{Conceptual Model and Literature Review}


Applying a broad innovation conceptualisation (such as that by Rogers (2003); see Introduction) allows for a general perception about the aggregate relationship between organisational characteristics and innovation across research domains, but limits insights into the multidimensional nature of innovation (Cooper, 1998). Particularly, different types of innovation do not have the same attributes (Downs \& Mohr, 1979), nor are they influenced to the same extent and direction by multi-level determinants (Damanpour, 1988). Indeed, Jaskyte (2011) and Corthouts and colleagues (2019) showed that even within one dichotomous dimension of administrative versus technical innovation types, organisational determinants relate to both innovation types differently.

Accordingly, innovation typology research aims to contribute to the development of a specific terminology that will enable practitioners to better understand which organisational determinants relate to what innovation type. Because typology research scholars have proposed a plethora of unrelated models containing the same concepts with different definitions, or vice versa, it is, however, difficult to understand the various types and their relationships (Crossan \& Apaydin, 2010). In addition to a labelled hierarchy of the innovation concepts studied, Figure 1 also presents an overview of previous innovation typology research. Initially, researchers proposed typologies on the basis of which a limited number of innovation types can be clearly distinguished from each other. For example, Knight (1967) distinguished product innovation, production process innovation, organisational structure innovation and people innovation. Subsequently, numerous typology researchers have attempted to develop an integrative model (Francis \& Bessant, 2005; Rowley et al., 2011) that is constructed on clear definitions so that the innovation types differ as much as possible from one another. These typologies provide a wealth of specific information about the 
determinants per type of innovation, but hinder a multi-dimensional view. In Rowley and colleagues' (2011) framework, for example, a product innovation cannot be administrative in nature. This goes against the idea of dichotomous innovation dimensions that consider every innovation as product/process, administrative/technical, commercial/social, etc. For example, Daft (1978) juxtaposes administrative versus technical innovations in his dual-core model. Some authors, such as Hoeber and colleagues (2015), go further and describe the innovation types that are implemented by VSCs on multiple dimensions, albeit per dimension separately.

Contemporary research agrees that every innovation can be described by multiple distinct attributes and therefore should not be approached unidimensional (Rowley et al., 2011). In response to this 'dimensionality problem', Cooper (1998) developed a model to observe innovation from the combination of three innovation dimensions, namely 'form' (process versus product), 'nature' (administrative versus technical) and 'magnitude' (incremental versus radical), so that researchers could be more successful in describing relationships between innovation types. Cooper's (1998) model accedes to the theoretical uniqueness of every innovation, but creates the practical problem that every innovation 'floats' within the space of the model. As a result, the innovations in the model cannot be quantified into distinct types and thus, no empirical comparative study can be performed. The problem is situated at the 'magnitude' dimension, where innovations are more vaguely distinguished on a continuum between incremental-radical, while the other dimensions contain clearer dichotomies (Hoeber et al., 2015). Moreover, innovation in $\mathrm{NP}(\mathrm{S}) \mathrm{Os}$ is seen as the cumulative result of continuous incremental (rather than radical) innovations (Hoeber et al., 2015; Walker, 2007). Therefore, the current study proposes a 3D-model (see Figure 2) of innovation of which two of the three dimensions (i.e. 'form' and 'nature') 
correspond to Cooper's (1998) model. In replacement for magnitude, this study includes the dichotomous 'goal' dimension between commercial and social innovation. In this light, commercial innovation is defined as an innovation that is motivated by economic revenue maximisation ${ }^{2}$ (Pol \& Ville, 2009), whilst social innovation concerns nonfinancial related goals, such as social inclusion (Corthouts et al., 2019). Where the 'magnitude' of NPSOs' innovations is rarely radical, it can be expected that the proportion between social and commercial innovations within the 'goal' dimension will be more balanced. In this regard, van der Roest and colleagues (2016) point to the commercialisation and marketisation of NPSOs that "have commercial activities designed to earn money for the association's other activities" (Ibsen \& Seippel, 2010, p. $605)$.

In sum, the dimensions 'form', 'nature' and 'goal' are intersected so that eight octants (innovation types) are obtained: commercial administrative product (CAPt), commercial administrative process (CAPs), commercial technical process (CTPs), commercial technical product (CTPt), social administrative product (SAPt), social administrative process (SAPs), social technical process (STPs), and social technical product (STPt) innovations. It is important that the 3D-model (Figure 2) presented in this paper should not be considered exhaustive, because every innovation is unique in a certain area, but as a useful comparative extension of Cooper's (1998) model.

\footnotetext{
${ }^{2}$ Contrary to profit maximisation, the principle of revenue maximisation is pursued by NPSOs through additional (innovative) commercial activities intended to generate (extra) income, which is spent on the non-profit purpose for which the association was founded.
} 
Figure 2. The Conceptual 3D-Model of Innovation

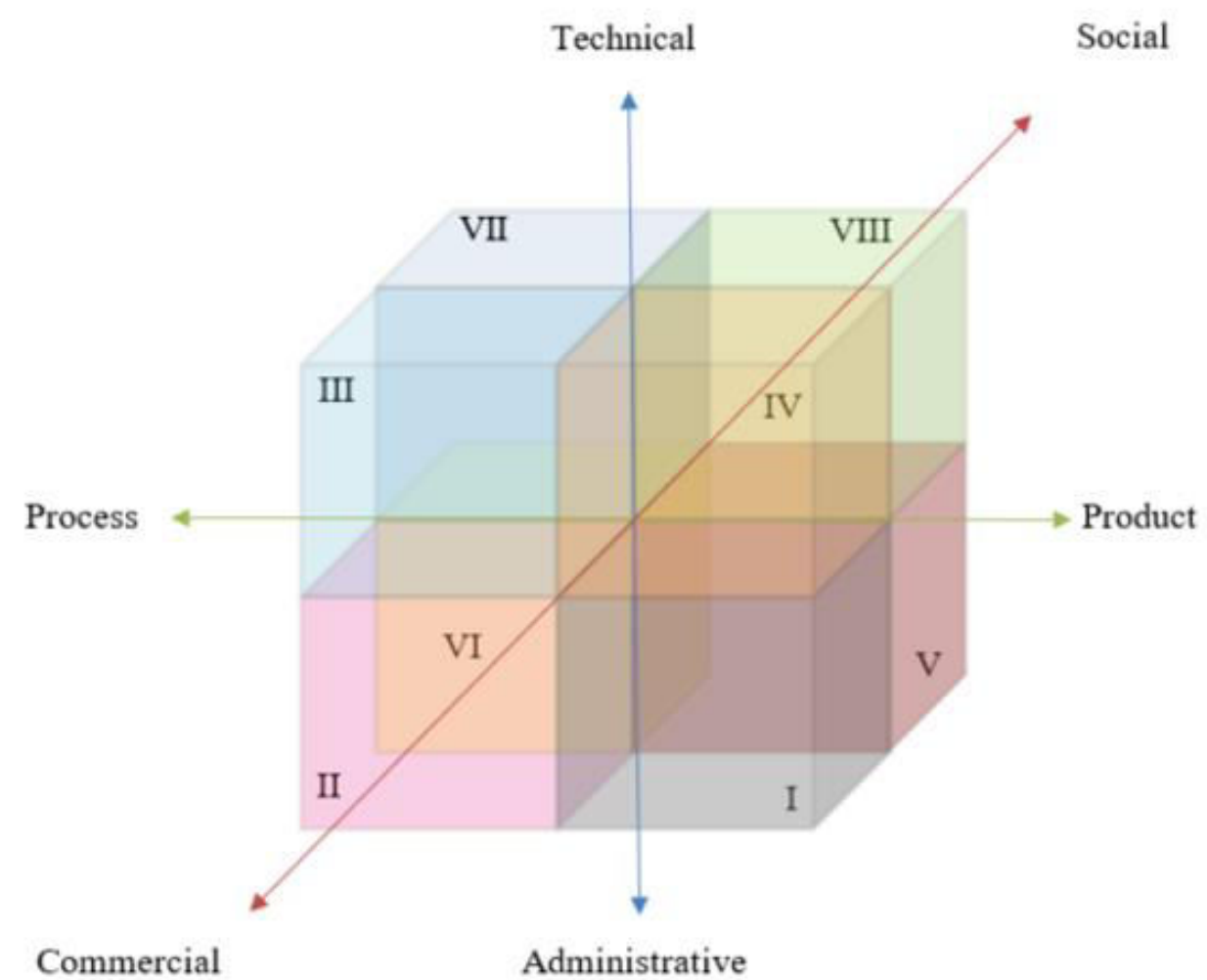

\section{Conceptual Model Dimensions}

Below, the three dimensions of the model will be described in order to inquire to what extent NPSO types implement innovations (differently) (RQ1).

\section{Form}

Each innovation can be categorised by 'form' as a product or process innovation (Damanpour et al., 2009; Francis \& Bessant, 2005). Product (or service) innovations have an external focus driven by the demands of their clients resulting in a differentiation of the organisation's output (Cooper, 1998). In contrast, process 
innovations have an internal focus and aim at increasing the organisations' processes' efficiency and effectiveness (Damanpour et al., 2009).

Concerning NPSOs, Winand and colleagues (2016) investigated the implementation of service innovations, like online services, by SFs. They found that 101 regional SFs implemented on average 4.53 service innovations over a four-year time period. Hoeber and colleagues (2015) juxtaposed the number of process innovations with product innovations of community sports organisations (CSOs). Their findings show that CSOs implement a higher number of process than product innovations.

However, data on the implementation of product and process innovations by LSAs are lacking, let alone comparative figures between the three different NPSO types. Therefore, building on the organisation-specific studies' findings, this study will test the following hypothesis (H1): all three NPSO types implement product-related innovation types to a lesser extent than process-related innovation types.

\section{Nature}

A second dimension used frequently is the 'nature' of innovation (Crossan \& Apaydin, 2010) with two opposing attributes: technical versus administrative. This dimension "involves the dichotomy of change in relation to the organisation's operating core" (Cooper, 1998, p. 498). In this regard, a technical innovation relates to the basic work activity and technological core of the organisation, while an administrative innovation relates to the social system of the organisation (Crossan \& Apaydin, 2010).

Most $\mathrm{NP}(\mathrm{S}) \mathrm{O}$ related research has focused on the implementation of techn(olog)ical innovation (Balmer et al., 2012; Desbordes, 2001). This is remarkable, 
as Hoeber and colleagues (2015) found that CSOs implemented more administrative (59\%) innovations as opposed to 'only' $41 \%$ technical innovations.

Again, the current state of research concerning the 'nature' dimension offers no solace in comparing several NPSO types. Starting from the findings of Hoeber and colleagues (2015), this study attempts to close this research gap by hypothesising that VSCs, compared to SFs and LSAs, implement more administrative-related innovations (H2).

Goal

The third dimension addressed in the model is the 'goal' of the implemented innovation. Corresponding to Pol and Ville (2009), this study contrasts social with business (henceforth commercial) as opposing innovation attributes. In the sports context, Tjønndal (2017) has already distinguished social and commercial innovation in her typology alongside technological, organisational and community-based innovation. Tjønndal (2017) conceptualises commercial and social innovations respectively as new ideas motivated by increasing revenues (e.g. by selling new sports products) and new activities for resolving societal problems, such as integrating disadvantaged groups (Corthouts et al., 2019; Mulgan et al., 2007; Pol \& Ville, 2009). Even though Tjønndal's (2017) innovation types, in contrast to the 3D-model, are not viewed within overarching dimensions (see Figure 1), her conceptualisation is similar to this study's understanding of commercial and social innovation.

Whilst the government encourages all three NPSOs to innovate with a social 'goal' (Scheerder et al., 2014), the importance of professionalisation as "the process by which sports organisations transform from a volunteer-driven to an increasingly business-like phenomenon" (Dowling et al., 2014, p. 528) is increasingly emphasised. 
Indeed, this trend towards a professionalised 'business-like' approach has already been observed within public sports organisations (such as LSAs) (Houlihan, 1988), VSCs (Seippel, 2002) and SFs (Ruoraren et al., 2016).

In contrast to the previous innovation dimensions, both commercial and social innovations within the three NPSO types under investigation in this study have already been examined in previous research. However, an important limitation is that previous studies did not consider the proportion between the two attributes (as part of one dichotomous dimension). Despite the fact that Flemish SFs, VSCs and LSAs have been called upon by a decree to professionalise (Flemish Government, 2016), this study therefore hypothesises that, based on a fundamental social non-profit logic in these organisation types' operations, all three NPSO types will implement more innovation types with a social then with a commercial 'goal' (H3).

\section{Literature Review of Innovation Determinants}

Despite the uncertainty about possible associations between determinants and innovation types, researchers agree that an effect can occur at various levels (Crossan \& Apaydin, 2010). Notwithstanding that VSCs, SFs and LSAs occupy a different position within the sports landscape (cf. context), from their similarities (such as their role as a non-profit sports provider) the same determinants (whether or not via proxy variables) as in previous research can be taken into account. In the context of NPSOs this means, among other determinants, that the attitudes of a NPSO's key representative, such as the president, can be investigated at the managerial level, at the organisational level, aspects of policy or finance, and at the environmental level, partnerships (Hoeber \& Hoeber, 2012). Hence, a literature review of each level is conducted in clarifying which determinants predict the implementation of which types of innovation (RQ2). 


\section{Managerial}

At the micro-level, managerial attitudes of NPSOs (Crossan \& Apaydin, 2010; Hambrick \& Mason, 1984) are considered. Generally, positive attitudes towards change are expected to positively affect the innovation implementation (Damanpour, 1991; Winand \& Anagnostopoulos, 2017; Winand et al., 2013), as identified by Hoeber and Hoeber (2012) during the CSO's implementation process of a technological innovation.

Additionally, age is often taken into account at this level from the perspective of the managerial tenure (Damanpour, 1991; Vaccaro et al., 2010). Some studies hypothesise that managerial tenure is positively associated with the organisation's innovativeness, explained by the manager's obtained organisational knowledge of the usual course of events (Crossan \& Apaydin, 2010; Damanpour \& Schneider, 2006). Other studies explain their contradictory findings by the fresh impetus given by new, young managers to the organisation. In an attempt to clarify the direction of its influence, Jaskyte (2011) shows that the ambiguous effect of managerial tenure may be due to the 'nature' of innovation. While managerial tenure does not have a significant impact on technical innovations within NPOs, it does have a negative impact on administrative innovations.

\section{Organisational}

At the meso-level, the effect of organisational age on innovation types is studied. Accordingly, Jaskyte (2013) found that younger NPOs implemented more administrative innovations, such as employee and volunteer rewards, because of their hands-on behaviour. 
The organisation's size is also generally regarded as an important determinant, operationalised by a variety of measures, such as number of assets, members or employees (Sciulli, 1998). As LSAs do not affiliate members, such as VSCs and SFs, the number of employees is observed as a comparable proxy variable for size (Damanpour, 1991). Daft (1978) found that a low professional level, as the percentage of certified personnel, influences the implementation of administrative innovations positively, but inversely for technical innovations. Additionally, it is emphasised that organisational size will be a positive predictor of product innovations, as large organisations are better able to afford the developmental costs of new ideas (Sciulli, 1998).

Additionally, the organisation's economic health affects the implementation of different innovation types. An organisation with a more positive perception of its financial capacity is argued to more easily afford taking risks with the experimentation of new products (Subramanian \& Nilakanta, 1996). Based on their finding that financially secure SFs implement significantly less general (administrative) innovations, Winand and colleagues (2013) contrarily argue that financially secure organisations do not feel the urge to undergo major organisational changes, precisely because they already have a solid financial status. Contrariwise, organisations with a shortage of resources are encouraged to develop more marketisation and organisation (both administrative) innovations (Walker, 2007).

Furthermore, Crossan and Apaydin (2010) recognise the (i) organisational mission and strategy and (ii) organisational learning and knowledge management tools as organisational-level determinants. First, an organisational mission and strategy give direction to the organisation by means of a clear guiding policy. Through governmental implicit tactics (via promotions) or explicit strategies (via decrees), NPSOs not only 
pursue sports policy objectives, but also focus on policy areas such as youth, healthy exercise, injury prevention, low threshold sports, diversity, general health and innovation (Breuer et al., 2017; Feiler et al., 2019; Ibsen \& Jørgensen, 2002; Meganck et al., 2015; Skille, 2010; Winand et al., 2013; 2016). Second, organisational learning and knowledge management tools reflect the provision of support for experimentation, formal information gathering, etc. (Crossan \& Apaydin, 2010). Although internal knowledge creation is believed to reduce environmental dependency and facilitate absorptive capacity (Cohen \& Levinthal, 1990), higher internal involvement also mainly leads to a more difficult implementation of administrative innovations (Subramanian \& Nilakanta, 1996).

\section{Environmental}

At the macro-level, the organisation's relationship with the environment is investigated. In response to internal knowledge creation (see above), Chesbrough (2006) argues for open innovation as sharing knowledge with external stakeholders. Indeed, external communication, in which specialised knowledge is shared with stakeholders outside the organisation, seems favourable to implement service (administrative) innovations (Walker, 2007). Elaborating on this, Wemmer and colleagues (2016) found that 'coopetition', i.e. collaborating with competitors, has a positive impact on the use of outside knowledge, which in turn influences the implementation of innovations positively (Wemmer et al., 2016).

In addition, competition without collaboration can stimulate innovation too. Indeed, Winand and colleagues (2013) found that sports federations with high perceptions of a competitive environment are significantly more innovative, particularly with regard to general (i.e. administrative) service innovations. 


\section{Methods}

\section{Data Collection}

The current study investigates NPSOs in Flanders, the Dutch-speaking part of Belgium. The data were gathered through three online surveys approved by an ethics committee. The surveys that were sent to the SFs and the LSAs are part of the Flemish Sports Federation Panel and Flemish Local Sports Authority Panel, respectively, and were sent for the third time after 2010 and 2014 to all 70 recognised Flemish SFs and all 308 LSAs on March 6, 2018. In line with the previous three waves of the Flemish Sports Club Panel, the questionnaire for the VSCs was distributed concurrently (on March 6, 2018) via the LSAs to the VSCs within their municipality. In addition, previously participating VSCs wishing to be involved in future research were contacted directly. In accordance with Winand and colleagues' research (2013), key representatives (i.e. top management team affiliates; Hambrick \& Mason, 1984) of the NPSOs were asked to complete the survey. Each panel consists of six blocks about general information (e.g. age), specific organisational information (e.g. board composition), members (e.g. demographics), innovation (e.g. implemented innovations), infrastructure and financial information (e.g. income perception). In this process, some questions are unique and others identical for the panels. In total, useful questionnaires from 44 SFs, 176 LSAs and 562 VSCs were collected from 6 March 2018 until 31 July 2018.

\section{Variables}

Dependent Variables 
Elaborating on Winand and colleagues' (2013) research and the Community Innovation Survey (Eurostat, 2019), respondents were asked to describe the innovations they had implemented over the past four years using an extensive list of general innovation categories (Appendix C). Examples of general innovation categories include new Sports-for-All activities or online services. In agreement with Rogers' (2003) emphasis on the adopter's point of view, it was decided to approach innovation subjectively. As such, for every innovation, the respondents had to indicate if it concerned either a process or a product (i.e. 'form'), technical or administrative (i.e. 'nature') and social or commercial (i.e. 'goal') innovation. In order to reduce the complexity $^{3}$ of the question, a concise definition for each two attributes of the aforementioned three dimensions was provided (Appendix C). Furthermore, the innovations mentioned by participants were carefully reviewed by the lead author based on their descriptions. As a result, innovations without a (clear) description, for example, were not retained. As such, by combining the three dimensions, every innovation can be designated to one out of the eight innovation types that are distinguished in Table 1 and exemplified in Appendix A.

\section{Independent Variables}

In accordance with the multidimensional framework of Damanpour and Schneider (2006), the determinants were classified at the managerial, organisational and

\footnotetext{
${ }^{3}$ Probably due to the question's complexity, there was a drop-out from $78 \%$ before this question to $62 \%$ respondents afterwards. However, as for the entire sample, the SFs were measured representative of the population by decree and size. The same applies to LSAs and VSCs by geographical location, socio-economic profile and size (only for LSAs). Concerning the socio-economic profile, LSAs and VSCs are classified into a (i) residential, (ii) rural, (iii) industrial, (iv) semi-urban, (v) urban, or (vi) touristic areas, based on the demographic, cultural and financial characteristics of their environment.
} 
environmental level. First, at the managerial level, managerial tenure was operationalised in the current study as the number of years the respondents occupy their position (see Jaskyte, 2011). Second, at the organisational level, organisational age was measured via the foundation year of the organisation. As proxies for size and professionalisation (Dowling et al., 2014), the respondents had to indicate the number of volunteers and the number of paid full-time equivalents (FTE) of their organisation. Furthermore, as a measure for organisational mission and strategy (Crossan \& Apaydin, 2010), the respondents were asked to what extent they devote extra policy attention to seven policy areas (i.e. youth, healthy exercise, injury prevention, low thresholds sports, general health, diversity, and innovation). Per area, respondents had to tick the box whether they had paid extra attention to this by making a person outside (i) and/or within (ii) the board responsible, by spending a separate budget (iii), by including it in the policy plan (iv), and/or by organising specific actions (v). For each area, a composite index was created by adding up the number of 'yes' responses to the five different policy actions. Hence, one (continuous) scale variable from 0 to 5 was computed per organisation for each policy area. Finally, the respondents were asked to indicate to what extent persons/organisations were involved in the innovation process over the past four years (based on a Likert-scale of $1=$ never to $5=$ =very active). Dummy variables were created to distinguish the (very) actively (categories 4 and 5) internal stakeholders ( $\mathrm{N}=6$; see Appendix $\mathrm{C}$ ). For each organisation, one score was compiled based on the sum of the dummy variables (ranging from 0 to 6). Third, at the environmental level, the external stakeholders $(\mathrm{N}=8$; see Appendix $\mathrm{C})$ were calculated correspondingly via the sum of (a) (very) actively involved sports clubs, sports federations, Flemish government, Belgian Olympic and Inter-federal Committee, research institutions and private partners. 
In addition to the above rather structural parameters, 25 statements (on a Likertscale from 1=completely disagree to 5=completely agree; see Appendix C) were adapted from Winand and colleagues' (2013) study to investigate attitudinal innovation determinants within SFs, VSCs and LSAs. A principal component analysis with orthogonal rotation (varimax) was conducted on the 25 statements. The Kaiser-MeyerOlkin measure verified the sampling adequacy $(\mathrm{KMO}=.862)$ for the analysis. Five components had eigenvalues over Kaiser's criterion of 1 and in combination explained $58.60 \%$ of the variance. Appendix B shows the factor loadings after rotation. Clustered items about respondents' attitude towards change were identified on the managerial level as the willingness to change. Factors considering perceptions about the knowledge management and financial situation were labelled at the organisational level as organisational learning and economic health, respectively. Finally, the two remaining factors about the perception of collaborating with external partners and rivalry were classified at the environmental level as cooperation and entrepreneurship and competitive environment, respectively.

\section{Data Analysis}

With respect to RQ1, descriptive statistics were carried out to explore the extent to which VSCs, LSAs and SFs implement the eight innovation types. Using a Pearson's Chi Square test, the frequencies of each innovation type are compared between the three organisation types. In answering RQ2, the scales of the eight innovation types were dichotomised, so that organisations are distinguished that have implemented none $(=0)$ or at least one $(=1)$ particular innovation type. Binary logistic regression models were then conducted for all eight dummy variables of the innovation types. A block wise 
method was used to determine the cumulative variance explaining effect of the different levels of independent variables.

\section{Results}

Table 1 shows how many times each innovation type is implemented in total, by SFs, VSCs and LSAs, together with its proportion within the organisation's type. Overall, 904 innovations were implemented by the participating NPSOs over the past four years, of which most are STPt (30.5\%) or SAPt (20.4\%). To a lesser extent, CAPs (5.8\%) and CTPs (2.8\%) were implemented. On average, SFs implemented 1.61, LSAs 2.41, and VSCs 0.73 innovations.

A significant association exists between the innovation type and the organisation type $\left(\mathrm{X}^{2}=48.622 ; \mathrm{p}<.001\right)$ as the Bonferonni post-hoc tests illustrate that the proportion of STPt is significantly higher for SFs (39.4\%) and LSAs (34.4\%) in comparison with VSCs $(25.0 \%)$. In addition, LSAs have a lower proportion of STPs than SFs and VSCs. 
Table 1. Descriptive Statistics and Proportion of the 3D-Model Innovation Types per Organisation Type (1/3)

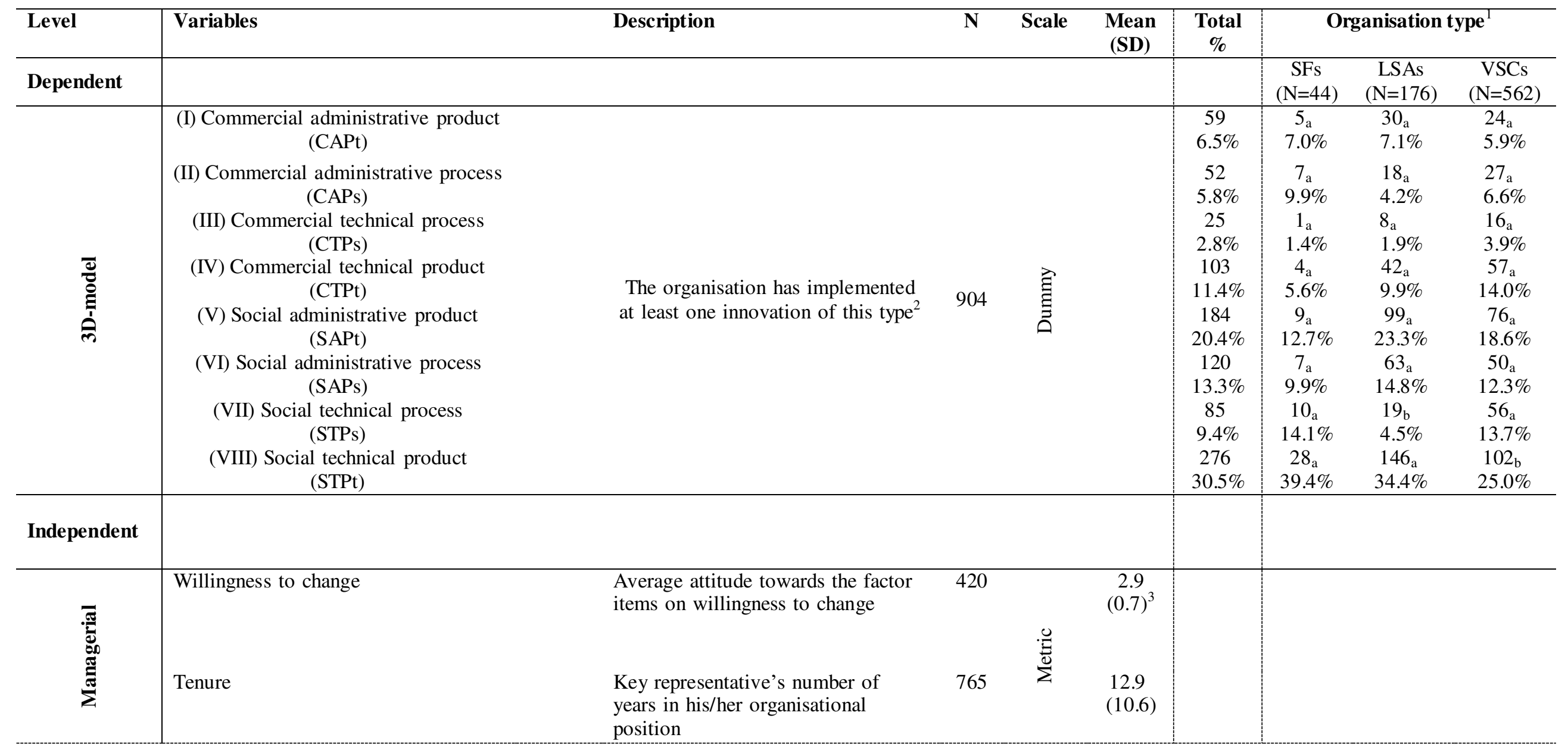


Table 1. Descriptive Statistics and Proportion of the 3D-Model Innovation Types per Organisation Type (2/3)

\begin{tabular}{|c|c|c|c|c|c|c|c|c|}
\hline Level & Variables & & Description & $\mathbf{N}$ & Scale & $\begin{array}{c}\text { Mean } \\
\text { (SD) }\end{array}$ & $\begin{array}{c}\text { Total } \\
\%\end{array}$ & Organisation type $^{1}$ \\
\hline \multicolumn{9}{|c|}{ Independent } \\
\hline 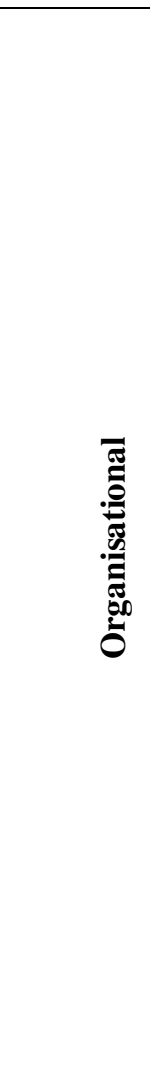 & $\begin{array}{l}\text { Organisational learning } \\
\text { Economic health } \\
\text { Age } \\
\text { Number of volunteers } \\
\text { Number of FTE } \\
\text { Youth policy } \\
\text { Healthy exercise policy } \\
\text { Injury prevention policy } \\
\text { Low threshold sports policy } \\
\text { General health policy } \\
\text { Diversity policy } \\
\text { Innovation policy }\end{array}$ & 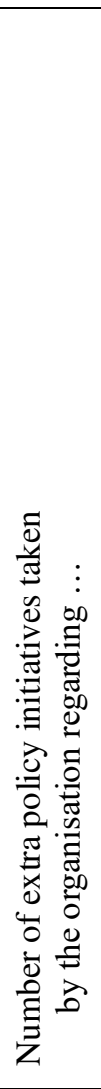 & $\begin{array}{l}\text { Average attitude towards the factor } \\
\text { items on organisations' knowledge } \\
\text { management } \\
\text { Average attitude towards the factor } \\
\text { items on organisations' financial } \\
\text { resources } \\
\text { Number of years that the } \\
\text { organisation exists } \\
\text { Number of volunteers } \\
\text { Number of full-time equivalents } \\
\ldots \text { youth (e.g. improving the quality } \\
\text { of youth training) } \\
\ldots \text { healthy exercise (e.g. increasing } \\
\text { health-enhancing sport-related } \\
\text { effects) } \\
\ldots \text { injury prevention (e.g. improving } \\
\text { the training structure for the athletes) } \\
\ldots \text { low threshold sports (e.g. offering } \\
\text { Sports-for-All services) } \\
\ldots \text { general health (e.g. promoting } \\
\text { healthy snacks) } \\
\ldots \text { diversity (e.g. integrating } \\
\text { disadvantaged groups) } \\
\ldots \text { innovation (e.g. offering new } \\
\text { sports products) }\end{array}$ & $\begin{array}{l}711 \\
701 \\
696 \\
697 \\
672\end{array}$ & $\frac{0}{e_{Z}^{0}}$ & $\begin{array}{c}3.2 \\
(0.8)^{3} \\
\\
2.8 \\
(1.0)^{3} \\
\\
36.6 \\
(27.7) \\
83.7 \\
(426.5) \\
4.1 \\
(17.7) \\
1.8 \\
(1.6) \\
1.0 \\
(1.2) \\
\\
0.7 \\
(1.1) \\
1.4 \\
(1.4) \\
0.9 \\
(1.2) \\
1.4 \\
(1.5) \\
0.7 \\
(1.1)\end{array}$ & & \\
\hline
\end{tabular}


Table 1. Descriptive Statistics and Proportion of the 3D-Model Innovation Types per Organisation Type (3/3)

\begin{tabular}{|c|c|c|c|c|c|c|c|}
\hline Level & Variables & Description & $\mathbf{N}$ & Scale & $\begin{array}{c}\text { Mean } \\
\text { (SD) }\end{array}$ & $\begin{array}{c}\text { Total } \\
\%\end{array}$ & Organisation type $^{T}$ \\
\hline \multicolumn{8}{|c|}{ Independent } \\
\hline : & Internal involvement & $\begin{array}{l}\text { Number of chairpersons, } \\
\text { administrative and/or technical } \\
\text { personnel and members who were } \\
\text { actively involved in the innovation } \\
\text { process }(\mathrm{N}=6)\end{array}$ & 782 & & $\begin{array}{l}0.8 \\
(1.0)\end{array}$ & & \\
\hline : & $\begin{array}{l}\text { Cooperation \& entrepreneurship } \\
\text { Competitive environment } \\
\text { External involvement }\end{array}$ & $\begin{array}{l}\text { Average attitude towards the factor } \\
\text { items on working together with } \\
\text { external parties } \\
\text { Average attitude towards the factor } \\
\text { items on competition between peer- } \\
\text { organisations } \\
\text { Number of sports clubs, federations, } \\
\text { Flemish government agencies, } \\
\text { Olympic Committees, research } \\
\text { institutions and private partners } \\
\text { which were actively involved in the } \\
\text { innovation process }(\mathrm{N}=8)\end{array}$ & $\begin{array}{l}420 \\
782\end{array}$ & $\frac{0}{\mathscr{E}^{0}}$ & $\begin{array}{c}2.8 \\
(0.8)^{3} \\
\\
3.0 \\
(0.9)^{3} \\
\\
0.3 \\
(0.8)\end{array}$ & & \\
\hline 官 & $\begin{array}{l}\text { SF } \\
\text { LSA } \\
\text { VSC }\end{array}$ & $\begin{array}{l}\text { Sports federation } \\
\text { Local sports authority } \\
\text { Voluntary sports club }\end{array}$ & $\begin{array}{l}44 \\
176 \\
562\end{array}$ & 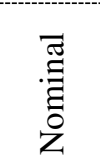 & & $\begin{array}{l}5.6 \% \\
22.5 \% \\
71.9 \%\end{array}$ & \\
\hline
\end{tabular}

1. Sports organisation types columns with the same letter in subscript do not significantly differ from each other at the .05 level.

2. Examples of every innovation type can be found in Appendix A.

3. After an exploratory factor analysis (see Appendix B), these variables were included in the binary logistic regressions as standardised factor scores with a mean of 0 and a standard deviation of

1. However, in function of interpretability, in this table the mean index values are shown on a Likert scale from $1=$ totally disagree to $5=$ totally agree. 
The binary logistic regression results (Table 2) show that, based on the pseudoR-squared statistics, the organisational and environmental factors particularly increase the model's fit. Notwithstanding that managerial variables determine the innovation types to a much lesser extent, the managerial willingness to change significantly affects the implementation of CTPt in a negative direction. Concerning the organisational level, age is positively associated with the implementation of CAPs, but negatively for SAPt. Specifically, with an increase of one year in organisational age, the odds of NPSOs implementing CAPs increase by nearly $2 \%$, but decreases by $1.1 \%$ for the implementation of SAPt. Additionally, an increase in the number of volunteers and FTE is positively related to the implemenation of SAPt and SAPs, respectively. For every extra volunteer and FTE, the NPSOs' implementation probability of SAPt and SAPs increases by $0.1 \%$ and $1.6 \%$, respectively. Apart from injury prevention, extra attention towards every other policy area is significantly related to one or more innovation types. Specifically, organisations that give extra attention to youth seem more likely to implement CTPt, but less likely CAPs. Furthermore, organisations that attach greater policy importance to healthy exercise appear less inclined to implement SAPs and CTPt, while they have a greater chance to implement SAPt. NPSOs that direct their policy towards low threshold sports are implementing CTPs to a lesser extent. In addition, significant negative relationships occur between general health policies, CAPt, and CAPs and between diversity policies and CTPt. On the contrary, a policy that is specialised on general health and on innovation seems beneficial for the implementation of SAPs and CAPt, respectively. As a last organisational factor, internal involvement has a significant positive effect on CTPt. At the environmental level, higher perceptions about the competitive environment has a negative association with the implementation of CTPt. Furthermore, an organisation is more likely to 
implement CAPs when more external stakeholders are involved. In comparison with VSCs, SFs implement more STPt. Lastly, a LSA is almost $85 \%$ less likely to implement a STPs than a VSC. 
Table 2. Results of the Binary Logistic Regressions ( $N=613)$

\begin{tabular}{|c|c|c|c|c|c|c|c|c|c|c|c|c|c|c|c|c|}
\hline & \multicolumn{2}{|c|}{ CAPt (I) } & \multicolumn{2}{|c|}{ CAPs (II) } & \multicolumn{2}{|c|}{ CTPs (III) } & \multicolumn{2}{|c|}{ CTPt (IV) } & \multicolumn{2}{|c|}{ SAPt (V) } & \multicolumn{2}{|c|}{ SAPs (VI) } & \multicolumn{2}{|c|}{ STPs (VII) } & \multicolumn{2}{|c|}{ STPt (VIII) } \\
\hline & S.E. & $\operatorname{Exp}(B)$ & S.E. & $\operatorname{Exp}(B)$ & S.E. & $\operatorname{Exp}(B)$ & S.E. & $\operatorname{Exp}(B)$ & S.E. & $\operatorname{Exp}(B)$ & S.E. & $\operatorname{Exp}(B)$ & S.E. & $\operatorname{Exp}(B)$ & S.E. & $\operatorname{Exp}(\mathrm{B})$ \\
\hline \multicolumn{17}{|l|}{ MANAGERIAL } \\
\hline Willingness to change & .223 & .990 & .226 & 1.189 & .511 & 1.738 & .160 & $.697^{*}$ & .131 & .961 & .152 & 1.067 & .171 & .722 & .112 & 1.198 \\
\hline Tenure & .025 & 1.009 & .025 & .960 & .043 & 1.010 & .019 & .984 & .014 & 1.007 & .017 & 1.019 & .019 & 1.003 & .012 & 1.003 \\
\hline \multicolumn{17}{|l|}{ ORGANISATIONAL } \\
\hline Organisational learning & .296 & 1.047 & .296 & 1.228 & .551 & 1.705 & .217 & .848 & .181 & .799 & .224 & 1.485 & .220 & 1.074 & .150 & .878 \\
\hline Economic health & .307 & 1.326 & .306 & .754 & .590 & 672 & .201 & .794 & .173 & 1.248 & .201 & .835 & .241 & 1.323 & .147 & 1.037 \\
\hline Age & .008 & .997 & .007 & $1.017 *$ & .015 & .983 & .005 & 1.007 & .006 & $.989 *$ & .006 & .998 & .006 & .997 & .004 & .999 \\
\hline Number of volunteers & .000 & 1.000 & .000 & 1.000 & .001 & .999 & .000 & 1.000 & .000 & $1.001 *$ & .000 & 1.000 & .000 & 1.000 & .000 & 1.000 \\
\hline Number of FTE & .010 & 1.018 & .026 & .970 & .049 & 1.010 & .009 & 1.0003 & .008 & .998 & .008 & $1.016 *$ & .011 & .997 & .006 & .993 \\
\hline \multicolumn{17}{|l|}{ Policy attention } \\
\hline Youth & .175 & .937 & .213 & $.650 *$ & .326 & 1.519 & .123 & $1.335^{*}$ & .103 & 1.032 & .123 & 1.033 & .128 & .791 & .089 & .941 \\
\hline Healthy exercise & .269 & 1.330 & .291 & 1.014 & .484 & 1.456 & .209 & $.580 * *$ & .159 & $1.394 *$ & .226 & $.569 *$ & .205 & 1.309 & .142 & .990 \\
\hline Injury prevention & .323 & .673 & .307 & 1.370 & .624 & .530 & .250 & 1.436 & .191 & .765 & .238 & 1.230 & .223 & .945 & .162 & 1.040 \\
\hline $\begin{array}{l}\text { Low thresholds } \\
\text { sports }\end{array}$ & .242 & 1.203 & .283 & 1.288 & .542 & $.200 * *$ & .188 & 1.303 & .165 & .717 & .195 & .914 & .198 & .950 & .133 & 1.181 \\
\hline General health & .252 & $.541 *$ & .291 & $.559 *$ & .501 & 1.641 & .159 & 1.143 & .127 & 1.043 & .149 & $1.416^{*}$ & .193 & .947 & .109 & .929 \\
\hline Diversity & .272 & .933 & .326 & 1.185 & .475 & 1.383 & .201 & $.662 *$ & .167 & 1.180 & .212 & .915 & .227 & 1.313 & .144 & 1.057 \\
\hline Innovation & .224 & $1.675^{*}$ & .229 & 1.058 & .439 & 2.019 & .161 & .879 & .138 & .965 & .163 & .943 & .202 & .802 & .114 & .932 \\
\hline Internal involvement & .232 & .905 & .249 & .900 & .443 & 1.243 & .177 & $1.984 * *$ & .133 & .828 & .156 & .881 & .181 & 1.032 & .115 & .958 \\
\hline \multicolumn{17}{|l|}{ ENVIRONMENTAL } \\
\hline Cooperation/entrepreneurship & .256 & 1.218 & .242 & .932 & .598 & 2.818 & .191 & .694 & .147 & 1.137 & .164 & 1.211 & .188 & 1.339 & .122 & .797 \\
\hline Competitive environment & .318 & 1.738 & .298 & .993 & .570 & .756 & .206 & $.623 *$ & .174 & 1.186 & .211 & .836 & .231 & 1.409 & .149 & .943 \\
\hline External involvement & .186 & .973 & .177 & $1.447 *$ & .356 & .897 & .149 & .760 & .120 & .900 & .130 & .994 & .144 & .818 & .092 & 1.175 \\
\hline \multicolumn{17}{|l|}{ CONTROL } \\
\hline \multicolumn{17}{|l|}{ Organisation type $\mathrm{a}^{\mathrm{a}}$} \\
\hline $\mathrm{SF}$ & .948 & 1.559 & 1.074 & .978 & 1.512 & .273 & .855 & .682 & 1.013 & .153 & .746 & 2.199 & .753 & 1.340 & .509 & $3.222 *$ \\
\hline LSA & 1.027 & .642 & 1.115 & 1.645 & 1.649 & 13.590 & .719 & .458 & .570 & 1.120 & .728 & 2.009 & .824 & $.160 *$ & .503 & 1.165 \\
\hline Nagelkerke-R-Square & $\begin{array}{l}.003^{1} ; .0 \\
.094^{3} ; .0\end{array}$ & $\begin{array}{l}78^{2} \\
95^{4}\end{array}$ & $\begin{array}{l}.012^{1} ; \\
.139^{3} ;\end{array}$ & $\begin{array}{l}17^{2} \\
40^{4}\end{array}$ & $\begin{array}{l}.007^{1} ; \text {; } \\
.170^{3} ; \text {. }\end{array}$ & $\begin{array}{l}153^{2} \\
199^{4}\end{array}$ & $\begin{array}{l}.006^{1} \\
.135^{3}\end{array}$ & $\begin{array}{l}91^{2} \\
39^{4}\end{array}$ & $\begin{array}{l}.003^{1} ; \\
.096^{3} ;\end{array}$ & $\begin{array}{l}186^{2} \\
108^{4}\end{array}$ & $\begin{array}{l}.009 \\
.058\end{array}$ & $\begin{array}{l}55^{2} \\
65^{4}\end{array}$ & $\begin{array}{l}.000^{1} \\
.091^{3}\end{array}$ & $\begin{array}{l}67^{2} \\
108^{4}\end{array}$ & $\begin{array}{l}.002^{1} \\
.054^{3}\end{array}$ & $\begin{array}{l}38^{2} \\
66^{4}\end{array}$ \\
\hline
\end{tabular}

a. The reference category is: VSC

$* \mathrm{p}<0.05, * * \mathrm{p}<0.01, * * * \mathrm{p}<0.001$

Each superscript letter denotes the Nagelkerke-R-Square per added block; 1=managerial, 2=organisational, 3=environmental, 4=control 


\section{Discussion}

In response to RQ1, SFs, LSAs and VSCs implement on average more innovations with a product (68.8\%) than with a process 'form' $(31.2 \%)$. This is not in line with H1 that NPSOs would implement process innovations more frequently due to their lower risk-cost ratio and increased potential for immediate organisational benefit (Winand et al., 2016). This may be explained by how respondents in this study were able to categorise innovations themselves. In line with the basic principle that innovation is a (subjective) matter of the unit of adoption (Rogers, 2003), a web-based innovation, such as a new online membership system, may have been implemented by one NPSO as a product to meet member needs, but by another process-related to facilitate the internal administration (see Hoeber et al., 2015).

Concerning the 'nature' of innovation, the findings of this study indicate more balanced proportions, albeit for each organisation type in favour of innovations with a technical attribute. The biggest proportional difference is found among SFs $(39.5 \%$ administrative versus $60.5 \%$ technical innovations), then among VSCs $(43.4 \%$ administrative versus $56.6 \%$ technical) and finally among LSAs (49.4\% administrative versus 50.6\% technical). Although these findings align with Jaskyte's (2011) results that NPOs implement more techn(olog)ical than administrative innovations, this is not according to this study's hypothesis (H2). Reasons for this study's inverse findings can be found in the fact that technical innovations are less constrained by law on Flemish NPSOs (Flemish Government, 2016; Hull \& Lio, 2006), in comparison with internal changes within the social (administrative) system. The high proportion of technical innovations may also be related to the increasing use of technology and social media (Corthouts et al., 2018; Winand et al., 2013). 
Finally, it is found that the innovations mainly aim at a social $(73.5 \%)$ as opposed to a commercial (26.5\%) 'goal'. This finding is consistent with the stated hypothesis (H3) that VSCs, LSAs and SFs, from their respectively predominantly orientation towards social, public and common goals (Scheerder et al., 2014), pursue social innovations (Ratten, 2016).

Next, with respect to RQ2, each innovation type of the 3D-model is discussed from the perspective of their cross-organisational occurrence and implementation determinants.

\section{Commercial Administrative Products}

In total, 59 CAPt (6.5\% of the total) are implemented by SFs, LSAs and VSCs. Extra general health and innovation policy initiatives emerge as significant determinants for this innovation. The more attention a NPSO pays to general health, the less likely it it will implement CAPt. The opposite relationship applies for extra innovation-attention. A clarification for the former effect could be that CAPt, such as a new brand logo, has no affinity with general health principles. Following Subramanian and Nilakanta's (1996) argument that an organisation with a high level of specialisation would have problems with the early and consistent implementation of administrative innovations, it seems likely that extra attention for innovation mainly applies to the 'goal' dimension of the innovation. In particular, NPSOs that pay more attention to innovation in their policies can commercialise an administrative product easier.

\section{Commercial Administrative Processes}

The SFs, VSCs and LSAs implemented 52 CAPs, like IT-consulting services. Although younger organisations are thought to implement more administrative 
innovations because of their flexibility and agility (Jaskyte, 2013), mature organisations have established routines, which younger firms lack, that enable them to efficiently steer internal processes (Rosenbusch et al., 2011), clarifying the positive influence of age. Remarkably, although CAPs comprise the internal organisation, external involvement has a positive relationship with its implementation. This links with open innovation (Chesbrough, 2006; Wemmer et al., 2016). To clarify with a brief example: when the organisational knowledge is insufficient to use a new IT-consulting programme for administrative accounting optimisation, external involvement is required. Finally, the findings show that CAPs are less likely related to youth or general health policies. Both areas have a well-founded social character, as a result of which NPSOs may not experience the need to gain a stronger market position in the context of these areas through a new administrative process.

\section{Commercial Technical Processes}

All organisation types implemented CTPs (e.g. appointment of a new manager) the least, with an average of $2.8 \%$ and no proportional differences between organisation types. The only negative significant determinant is extra policy attention towards low threshold sports. Since this policy area is mainly related to target groups, like people with low income, it is not surprising that this is negatively associated with the commercial purpose of CTPs. After all, the main task of a new manager is aimed at commercialising new sports offers. Subsequently, low-threshold sports groups are not the most ideal market segment.

\section{Commercial Technical Products}


Approximately one out of ten innovations by NPSOs are CTPt, such as new sporting events. Within every level, a significant determinant was found. The managerial willingness to change relates negatively to the implementation of CTPt, counter to the assumption that change-ready managements innovate their organisations (Hoeber \& Hoeber, 2012). This finding can be explained by the fact that the implementation of CTPt, such as new sporting events, presupposes little change within the operation and structure of the organisation (Winand et al., 2016). Managers who are less willing to change might therefore be more inclined to implement technical and product-related innovation types, rather than administrative and process-related ones. Another interpretation could be that individuals with low willingness to change are more sensitive to any incremental change that deviates from the status quo (Winand \& Anagnostopoulos, 2017). They may therefore be more likely to identify an adapted/new CTPt as innovation, as opposed to managers pursuing change.

Even without strong organisational changes, internal involvement in the implementation of CTPt seems important. This can be attributed to the increase of interorganisational knowledge that is beneficial for a commercial product innovation.

The negative associations between healthy exercise, diversity and the implementation of CTPt on the one hand, and its positive relationship with extra attention for youth on the other hand point to the earlier underlined focus of NPSOs on the latter target group. Although not all disadvantaged groups (such as elderly) seem to be reached equally yet (Scheerder et al., 2014), the organisations still seem to opt for extra specialised attention for young people via CTPt.

Finally, higher perceptions about the competitive environment show a negative association with the implementation of CTPt. An explanation might be that 
organisations within a competitive environment do not risk developing CTPt because they perceive the market to be already saturated.

\section{Social Administrative Products}

One fifth of the implemented innovations are SAPt, such as new club support programmes. Considering all other factors, the effect of the number of volunteers confirms Sciulli's finding (1998) that organisational capacity can be positively associated with product-related innovations. Furthermore, the findings indicate that it is more likely for a younger organisation to implement SAPt. In contrast to the implementation of CAPs, this is in line with the finding of Jaskyte (2013) that younger NPSOs implement more administrative innovations. While older organisations specialise in efficiently managing internal processes (Rosenbusch et al., 2011), younger organisations seem to be more sensitive to the need for new products or services for their target groups. Since extra healthy exercise attention is positively related to SAPt's, but negatively to CAPs' and SAPs' implementation, the explanation can be sought within the 'form' dimension. This may be due to the fact that NPSOs tend to align healthy exercise principles with the core activities they offer in function of the member (i.e. product), rather than with their internal procedures in function of efficiency and effectiveness (i.e. process) (Meganck et al., 2015).

\section{Social Administrative Processes}

Similar to SAPt, SAPs are least implemented by SFs, followed by VSCs and LSAs, albeit without significant differences. In addition to the negative association with healthy exercise policy attention, a positive relationship exists between organisational size and the implementation of SAPs, though here with respect to the number of FTEs. 
This result can be explained by the difference in 'form' between the two innovation types. In contrast to volunteers, FTEs mostly occupy a central management spot. In light of their position, FTE are the one that will use processes that facilitate the administration. Therefore, the more FTE, the more prevalent SAPs are.

\section{Social Technical Processes}

For STPs, a new membership system to facilitate the follow-up of members was mentioned as an example. Considering all other variables, it is found that only the organisation type determines whether STPs are implemented. Particularly, over the past four years, LSAs have implemented significantly fewer STPs (4.5\%) than SFs $(14.1 \%)$ and VSCs $(13.7 \%)$.

\section{Social Technical Products}

Finally, STPt, like new sports programmes, are the most prevalent innovations within the NPSOs (30.5\%). Again, only the organisation type appears to be a significant predictor. In contrast to VSCs, SFs are more likely to introduce STPt. SFs, motivated by subsidiary possibilities from the decree (Flemish Government, 2016), continuously look for new sports as well as innovative variants of an existing sport to broaden their offer to all groups of civil society (hence social), while this cannot be expected of every VSC that is founded with a very specific technical focus.

\section{Conclusion}

This study posits a new three-dimensional innovation model to distinguish eight innovation types. The 3D-model exposes the shortcomings of previous research, such as the impossibility of comparing the effect of determinants between studies (Damanpour, 
1991), and shows that many accepted associations between determinants and innovation attributes do not apply, or are even reversed. This is because previous research has generally considered only one innovation attribute/dimension. A determinant might therefore explain the level of innovativeness overall, but becomes non-significant when investigating specific innovation types. In addition to a multidimensional conceptualisation of innovation, this study also provides a unique insight into the difference between three prototype NPSOs. Another contribution is the importance of looking at the extent to which organisations attach attention to different policy areas (such as youth and diversity), that effect the implementation of certain innovation types.

This study also faces some limitations. The 3D-model is not exhaustive and more intersections of dimensions would provide an even broader knowledge. However, this problem is infinite, since every innovation is unique. In that respect, it is not recommended to impose more dimensions on this model, but rather to examine one of the eight innovations in more detail. Additionally, further research will have to show whether the findings for other organisation types correspond with this study's results. An additional limitation that future studies can address is the issue of omitted variable bias. A drawback of the unique comparative data between organisation types of this study is that organisation-specific variables that may be relevant determinants were not included in the models or were included as proxies (e.g. number of employees as a measure of organisation size rather than number of members (which is not applicable to LSAs)). Furthermore, the present results come exclusively from quantitatively collected survey material. A limitation of this method is that the results depend on the respondents' different perceptions about change and innovation. The managerial level appeared to explain the variance of the innovation types only to a very limited extent, counter to previous research (Winand et al., 2013). This may be due partly because of 
the survey method whereby something small or not worth mentioning for one (favouring change), can be an important innovation for the other (resisting change). A post-hoc interview method would be appropriate to have a better understanding of their categorisation of innovations and the determinant-innovation relationship. Another possible avenue for future research could be to collect data at different levels (e.g. individuals and organisations), rather than having one representative per organisation complete the survey as was the case in this study. This would extend our understanding of determinants at the managerial, organisational and environmental level.

In summary, this study provides an overview of the innovative character of three Flemish prototype NPSOs and insight into the different determinants per innovation type. Thus, this study contributes to the empiricism regarding innovation by showing that a multidimensional view of innovation within multiple organisation types simultaneously affects the innovation-determinant association. A managerial implication is that (sports) organisations and policymakers can use this study's findings to create the most favourable managerial, organisational and environmental climate in relation to each innovation type, or vice versa (Sciulli, 1998). 


\section{References}

Balmer, N., Pleasance, P., \& Nevill, A. (2012). Evolution and revolution. Gauging the impact of technological and technical innovation on Olympic performance. Journal of Sports Sciences, 30(11), 1075-1083.

Breuer, C., Feiler, S., Llopis-Goig, R., \& Elmose-Østerlund, K. (2017). Characteristics of European sports clubs: A comparison of the structure, management, voluntary work and social integration among sports clubs across ten European countries. Odense: University of Southern Denmark.

Chesbrough, H. (2006). Open innovation: The new imperative for creating and profiting from technology. Boston: Harvard Business School Press.

Claes, E., Scheerder, J., Meganck, J., Vandermeerschen, H., Vos, S. \& Seghers, J. (2017). Barometer van de sportclubs in Vlaanderen. Het Vlaamse Sportclub Panel 3.0 (VSP3.0): Clubprofiel, sportaanbod en gezondheidspromotie (deel 2) [Barometer of sports clubs in Flanders. The Flemish Sports Club Panel 3.0: Club profile, sports offer and health promotion (part 2) (Sport Policy \& Management Studies 35). Leuven: KU Leuven/Policy in Sports \& Physical Activity Research Group.

Cohen, W. M. \& Levinthal, D. A. (1990). Absorptive capacity: A new perspective on learning and innovation. Administrative Science Quarterly, 35(1), 128-152.

Cooper, J. R. (1998). A multidimensional approach to the adoption of innovation. Management Decision, 36(8), 493-502.

Corthouts, J., Denys, A., Thibaut, E., \& Scheerder, J. (2018). Like it or not? The differences between and success factors of sports providers' use of social networking sites. Journal of Sport Management and Marketing, 19(1-2), 56-79.

Corthouts, J., Thibaut, E., Breuer, C., Feiler, S., James, M., Llopis-Goig, R., Perényi, S., \& Scheerder, J. (2019). Social inclusion in sports clubs across Europe: Determinants of 
social innovation. Innovation: the European Journal of Social Science Research, 33(1), 21-51.

Crossan, M. M. \& Apaydin, M. (2010). A multi-dimensional framework of organizational innovation: A systematic review of the literature. Journal of Management Studies, 47(6), 1154-1191.

Daft, R. L. (1978). A dual-core model of organizational innovation. Academy of Management Journal, 21(2), 193-210.

Damanpour, F. (1988). Innovation type, radicalness, and the adoption process. Communication Research, 15(5), 545-567.

Damanpour, F. (1991). Organizational innovation: A meta-analysis of effects of determinants and moderators. The Academy of Management Journal, 34(3), 555-590.

Damanpour, F. \& Schneider, M. (2006). Phases of the adoption of innovation in organizations: Effect of environment, organization and top managers. British Journal of Management, 17(3), 215-236.

Damanpour, F., Walker, R. M., \& Avellaneda, C. N. (2009). Combinative effects of innovation types and organizational performance: A longitudinal study of service organizations. Journal of Management Studies, 46(4), 650-675.

Desbordes, M. (2001). Innovation management in the sports industry: Lessons from the Salomon case. European Sport Management Quarterly, 1(2), 124-149.

Dowling, M., Edwards, J., \& Washington, M. (2014). Understanding the concept of professionalization in sport management research. Sport Management Review, 17(4), $520-529$.

Downs, G. W. \& Mohr, L. B. (1979). Toward a theory of innovation. Administration \& Society, 10(4), 379-408. 
Eurostat (2019). Community Innovation Survey. Retrieved from https://ec.europa.eu/eurostat/web/microdata/community-innovation-survey.

Feiler, S., Wicker, P., \& Breuer, C. (2019). Public subsidies for sport clubs in Germany: Funding regulations vs. empirical evidence. European Sport Management Quarterly, 19(5), 562-582.

Flemish Government (2016). Decreet houdende de erkenning en subsidiëring van de georganiseerde sportsector [Decree on the recognition and subsidization of the $\begin{array}{llll}\text { organized } & \text { sports } & \text { sector]. } & \text { Retrieved }\end{array}$ https://kics.sport.vlaanderen/Regelgeving/Gedeelde\%20\%20documenten/Sportfederati es/160610_Decreet_georganiseerde_sportsector.pdf.

Francis, D. \& Bessant, J. (2005). Targeting innovation and implications for capability development. Technovation, 25(3), 171-183.

Gratton, C. \& Taylor, P. (2000). Economics of sport and recreation. London: Spon Press.

Hambrick, D. \& Mason, P. (1984). Upper echelons: The organization as a reflection of its top managers. The Academy of Management Review, 9(2), 193-206.

Hoeber, L., Doherty, A., Hoeber, O., \& Wolfe, R. (2015). The nature of innovation in community sport organizations. European Sport Management Quarterly, 15(5), 518534.

Hoeber, L. \& Hoeber, O. (2012). Determinants of an innovation process: A case study of technological innovation in a community sport organization. Journal of Sport Management, 26(3), 213-223.

Houlihan, B. (1988). The professionalization of public sector sport and leisure management. Local Government Studies, 14(3), 69-82. 
Hull, C. E. \& Lio, B. H. (2006). Innovation in non-profit and for-profit organizations: Visionary, strategic, and financial considerations. Journal of Change Management, 6(1), 53-65.

Ibsen, B. \& Jørgensen, P. (2002). Denmark. The cultural and voluntary development of Sport for All. In: L. P. DaCosta \& A. Mragaya (Eds.). Worldwide experiences and trends in Sport for All (293-322). Oxford: Meyer \& Meyer Sport.

Ibsen, B., \& Seippel, Ø. (2010). Voluntary organized sport in Denmark and Norway. Sport in society, 13(4), 593-608.

Jaskyte, K. (2011). Predictors of administrative and technological innovations in nonprofit organizations. Public Administration Review, 71(1), 77-86.

Jaskyte, K. (2013). Does size really matter? Organizational size and innovations in nonprofit organizations. Nonprofit Management and Leadership, 24(2), 229-247.

Knight, K. E. (1967). A descriptive model of intra-firm innovation process. Journal of Management, 40(4), 478-96.

Meganck, J., Scheerder, J., Thibaut, E., \& Seghers, J. (2015). Youth sports clubs' potential as health-promoting setting: Profiles, motives and barriers. Health Education Journal, 74(5), 531-543.

Morris, L. (2013). Three dimensions of innovation. International Management Review, 9(2), $5-10$

Mulgan, G., Tucker, S., Ali, R., \& Sanders, B. (2007). Social innovation: What it is, why it matters and wow it can be accelerated. London, UK: The Young Foundation.

Pol, E. \& Ville, S. P. (2009). Social innovation: Buzz word or enduring term?. Journal of Socio-Economics, 38(6), 878-885.

Ratten, V. (2016). Sport innovation management: Towards a research agenda. Innovation: Management, Policy \& Practice, 18(3), 238-250. 
Rogers, E. (2003). Diffusion of innovations (5th Edition). New York: Free Press.

Rosenbusch, N., Brinckmann, J., \& Bausch, A. (2011). Is innovation always beneficial? A meta-analysis of the relationship between innovation and performance in SMEs. Journal of Business Venturing, 26(4), 441-457.

Rowley, J., Baregheh, A., \& Sambrook, S. (2011). Towards an innovation-type mapping tool. Management Decision, 49(1), 73-86.

Ruoranen, K., Klenk, C., Schlesinger, T., Bayle, E., Clausen, J., Giauque, D., \& Nagel, S. (2016). Developing a conceptual framework to analyse professionalization in sport federations. European Journal for Sport and Society, 13(1), 55-74.

Scheerder, J. (2007). Tofsport in Vlaanderen: groei, omvang en segmentatie van de Vlaamse recreatiesportmarkt [Sports-for-All in Flanders. Evolution and segmentation]. Antwerpen: F\&G Partners.

Scheerder, J., Claes, E., \& Vanreusel, B. (2014). Sportief (en) innovatief in een veranderende samenleving. Een verkennende analyse van good practices als inspiratie voor de clubsport van de toekomst [Sportive (and) innovative in a changing society. An exploratory analysis of good practices as inspiration for the sports clubs of the future]. (Sport Policy \& Management Studies 22). Leuven: KU Leuven/Policy in Sports \& Physical Activity Research Group.

Scheerder, J., Corthouts, J., Thibaut, E., Borgers, J. (contr.) (2021). Sport. Beleid en participatie in Vlaanderen. [Sport. Policy and participation in Flanders]. (Management \& Governance in Sport (MBS), 11). Leuven: LannooCampus.

Sciulli, L. M. (1998). How organizational structure influences success in various types of innovation. Journal of Retail Banking Services, 20(1), 13-18.

Seippel, Ø. (2002). Volunteers and professionals in Norwegian sport organizations. Voluntas: International Journal of Voluntary and Nonprofit Organizations, 13(3), 253-270. 
Skille, E. A. (2010). Competitiveness and health: The work of sport clubs as seen by sport clubs representatives. A Norwegian case study. International Review for the Sociology of Sport, 45(1), 73-85.

Sport Flanders (2020). Sports clubs. Retrieved on January 52020 via https://www.sport.vlaanderen/kennisplatform/sportclubs/.

Subramanian, A. \& Nilakanta, S. (1996). Organizational innovativeness: Exploring the relationship between organizational determinants of innovation, types of innovations, and measures of organizational performance. Omega, 24(6), 631-647.

Tjønndal, A. (2016). Sport, innovation and strategic management: A systematic literature review. Brazilian Business Review, 13, 38-56.

Tjønndal, A. (2017). Sport innovation: Developing a typology. European Journal for Sport and Society, 14(4), 291-310.

Vaccaro, I. G., Jansen, J. J. P., Van Den Bosch, F. A. J., \& Volberda, H. W. (2010). Management innovation and leadership: The moderating role of organizational size. Journal of Management Studies, 49(1), 28-51.

van der Roest, J. W., van Kalmthout, J., \& Meijs, L. (2016). A consumerist turn in Dutch voluntary sport associations?. European Journal for Sport and Society, 13(1), 1-18.

van Poppel, M., Claes, E., \& Scheerder, J. (2018). Sport policy in Flanders (Belgium). International Journal of Sport Policy and Politics, 10(2), 271-285.

Vos, S., \& Scheerder, J. (2014). Fact or fiction? An empirical analysis of cooperation between mass sport providers at the local level. European Journal for Sport and Society, 11(1), 7-34.

Walker, R. (2007). An empirical evaluation of innovation types and organizational and environmental characteristics: Towards a configuration framework. Journal of Public Administration Research and Theory, 18(4), 591-615. 
Weisbrod, B. A. (2009). The nonprofit economy. Cambridge: Harvard University Press.

Wemmer, F., Emrich, E., \& Koenigstorfer, J. (2016). The impact of coopetition-based open innovation on performance in nonprofit sports clubs. European Sport Management Quarterly, 16(3), 341-363.

Winand, M. \& Anagnostopoulos, C. (2017). Get ready to innovate! Staff's disposition to implement service innovation in non-profit sport organisations. International Journal of Sport Policy and Politics, 9(4), 579-595.

Winand, M., Scheerder, J., Vos, S., \& Zintz, T. (2016). Do non-profit sport organisations innovate? Types and preferences of service innovation within regional sport federations. Innovation: Management, Policy \& Practice, 18(3), 289-308.

Winand, M., Vos, S., Zintz, T., \& Scheerder, J. (2013). Determinants of service innovation: A typology of sports federations. International Journal of Sport Management and Marketing,

$13(1 / 2)$,

$55-73$. 